\title{
PENGEMBANGAN MODEL KOMPUTERISASI SIKLUS AKUNTANSI BERBASIS PROBLEM BASED LEARNING
}

\author{
Ni Luh Gede Erni Sulindawati \\ Gede Adi Yuniarta
}

\author{
Universitas Pendidikan Ganesha, Jl. Udayana 11 Singaraja \\ e-mail: ernisulindawatiayu@yahoo.co.id
}

\begin{abstract}
Computerized Model Development Accounting Cycle Based Problem Based Learning. Professionals in the field of accounting require professional ability in the use of technology to be able to exist in the face of the demands of the global era. Various developments are appropriately technology can be utilized to improve competence in the field of accounting. Eligibility required more of an ability to combine technology development with the field of accountting in order to solve various accounting cases in the world of work. This study is a continuation of previous research that has resulted in a computerized models of accounting cycle based on Problem Based Learning. This study uses a model of the development of learning tools Instructional Development Models (ID Model). Stage activities of this model is divided into: Problem Determination, Design and Development, and Implementation. The results showed that: (1) the product of research can be used as a place of learning for students to review in depth understanding of accounting theory, accounting systems as well as for their ability to take advantage of advances in technology to solve cases of accountting, (2) the product of research can be used as a tool in the learning interacttion, (3) research products can be used as a learning resource.
\end{abstract}

Keywords: computerized, accounting cycle and problem based learning

\begin{abstract}
Abstrak: Pengembangan Model Komputerisasi Siklus Akuntasi Berbasis Problem Based Learning. Tenaga profesional di bidang akuntansi memerlukan kemampuan profesional dalam pemanfaatan teknologi untuk dapat tetap eksis di dalam menghadapi tuntutan era global. Berbagai perkembangan teknologi sudah selayaknya dapat dimanfaatkan guna meningkatkan kompetensi di bidang akuntansi. Diperlukan kompentensi lebih berupa kemampuan mengkombinasikan perkembangan teknologi dengan bidang ilmu akuntansi guna memecahkan berbagai kasus akuntansi di dunia kerja. Penelitian ini merupakan kelanjutan penelitian sebelumnya yang sudah menghasilkan model komputerisasi siklus akuntansi berbasis Problem Based Learning. Penelitian ini menggunakan model pengembangan perangkat pembelajaran Instructional Development Model (ID Model). Tahap kegiatan dari model ini dibagi menjadi: Determinasi Masalah (Problem Determination), Desain (Design) dan Pengembangan (Development) dan Implementasi (Implementation). Hasil penelitian menunjukkan bahwa: (1) produk penelitian dapat dimanfaatkan sebagai wadah pembelajaran bagi mahasiswa untuk mengulas secara mendalam pemahaman teori akuntansi, sistem akuntansi serta kemampuan di dalam memanfaatkan kemajuan teknologi untuk menyelesaikan kasus-kasus akuntansi, (2) produk penelitian dapat dimanfaatkan sebagai alat bantu dalam interaksi pembelajaran, (3) produk penelitian dapat digunakan sebagai sumber belajar.
\end{abstract}

Kata-kata Kunci: komputerisasi, problem based learning, siklus akuntansi

Tenaga profesional di bidang akuntansi juga memerlukan kemampuan profesional dalam pemanfaatan teknologi untuk dapat tetap eksis di dalam menghadapi tuntutan era global. Berbagai perkem- bangan teknologi sudah selayaknya dapat dimanfaatkan guna meningkatkan kompetensi di bidang akuntansi. Salah satu mata kuliah yang mengkaji kombinasi bidang ilmu akuntansi dan perkem- 
bangan teknologi adalah mata kuliah komputer akuntansi (Buku Pedoman Studi, 2012). Penguasaan mahasiswa dalam mata kuliah ini ditujukan supaya mahasiswa dapat mengkombinasikan perkembangan teknologi dengan bidang ilmu akuntansi guna memecahkan berbagai siklus akuntansi pada berbagai jenis bidang usaha yang ada baik untuk perusahaan jasa, dagang bahkan untuk perusahaan manufaktur (Profil Jurusan Akuntansi, 2012).

Kenyataan di lapangan selama proses pembelajaran berbagai permasalahan kompleks muncul, mahasiswa menemui kesulitan dalam hal penguasaan dan pemahaman mata kuliah komputer akuntansi dalam menyelesaikan siklus akuntansi. Karakteristik mata kuliah yang menuntut kemampuan kompleks dari mahasiswa menyebabkan penguasaan tentang ilmu tersebut menjadi agak sulit. Dalam mata kuliah komputer akuntansi proses transfer pengetahuan menjadi sangat kompleks mengingat bukan hanya tentang komputer saja yang dikaji namun berbagai pemahaman bidang akuntansi terlebih dahulu harus sudah dipahami termasuk sistem informasi akuntansi. Selain itu permasalahan mengenai skill penggunaan komputer yang menuntut pemahaman mahasiswa tentang sistem komputer ditambah permasalahan klasik seperti keterbatasan waktu.

Salah satu model pembelajaran yang sering digunakan dalam proses belajar mengajar adalah pembelajaran berbasis masalah (Problem Based Learning). Model ini juga dikenal dengan nama lain seperti project based teaching, experienced based education, dan anchored instruction (Ibrahim dan Nur, 2004). Pembelajaran ini membantu siswa belajar isi akademik dan keterampilan memecahkan masalah dengan melibatkan mereka pada sistuasi masalah kehidupan nyata. Menurut Wina Sanjaya (2006) aspek psikologi belajar strategi pembelajaran berbasis masalah bersandarkan kepada psikologi kognitif yang berangkat dari asumsi bahwa belajar adalah perubahan tingkah laku berkat adanya pengalaman. Belajar bukan semata-mata proses menghafal sejumlah fakta, tetapi suatu proses interaksi secara sadar individu dan lingkungannya. Masalah-masalah disiapkan sebagai stimulus pembelajaran. Pembelajar dihadapkan pada situasi pemecahan masalah, dan guru hanya berperan memfasilitasi terjadinya proses belajar dan memonitor proses pemecahan masalah.

Dari berbagai uraian di atas maka upaya yang mungkin dilaksanakan untuk dapat meningkatkan kualitas pembelajaran dalam mata kuliah komputer akuntansi adalah dengan memanfaatkan perkembangan teknologi terutama perkembangan Information and Commonication Technology sebagai media pembelajaran dikombinasikan dengan pembahasan kasus-kasus akuntansi berbasis Problem Based Learning. Pemanfaatan perkembangan tersebut di antaranya dengan mengembangkan suatu program berupa komputerisasi siklus akuntansi berbasis ICT. Program komputer ini membantu mengolah data keuangan untuk diolah menjadi berbagai informasi keuangan. Dengan keunggulan system multi user access yang memungkinkan proses pembelajaran dalam sistem jaringan (LAN) sehingga proses transfer ilmu secara multimedia dapat dipenuhi. Sistem Multi User access ini juga memungkinkan pekerjaan akuntansi dapat dibagi dalam kelompok kerja dengan beberapa komputer yang berhubungan sehingga pembagian beberapa divisi akuntansi dapat dilakukan. Proses pembelajaran seperti ini akan dapat menunjukkan kondisi real di dunia kerja (berbasis Problem Based Learning) dan kualitas pembelajaran diharapkan dapat ditingkatkan.

\section{METODE}

Dalam kegiatan ini digunakan model pengembangan perangkat pembelajaran Instructional Development Model (ID Model) Model pengembangan perangkat pembelajaran ini merupakan model yang diusulkan oleh Logan (1982, dalam Knirk and Gustafon.1986) dan merupakan rekomendasi oleh UNESCO. Tahap kegiatan dari model ini dibagi menjadi: Determina-si Masalah (Problem Determination), Desain (Design) dan Pengembangan (Development). Penelitian dilaksanakan selama dua tahun. Pada penelitian di tahun pertama (2014) tahapan penelitian yang dilakukan adalah Determinasi Masalah (Problem Determination) dan Desain (Design). Hasil penelitian di tahun pertama menghasilkan draf model komputerisasi siklus akuntansi berbasis Problem Based Learning yang siap untuk diujicobakan pada penelitian ditahun berikutnya.

\section{HASIL PEMBAHASAN}

Kasus akuntansi yang disiapkan lebih mendekati kondisi riil di dunia usaha, lebih fleksibel mengingat kondisi dunia usaha yang fleksible serta keterkaitan dengan bidang lain seperti asuransi, sistem perbankan, perpajakan dan lainnya. Kasus akuntansi yang dibahas juga diharapkan 
tidak kaku cenderung mendekati contoh-contoh yang ada di buku saja namun sudah mengarah pada kondisi yang dapat meningkatkan kemampuan analisa dan kemampuan prediksi mahasiswa. Seiring dengan hal tersebut kertas kerja akuntansi yang disiapkan diharapkan juga disesuaikan secara khusus dengan kasus akuntansi yang dihadapi, kertas kerja selayaknya sistematis dan memiliki format terkini selayaknya yang berlaku di dunia kerja.

Strategi pembelajaran yang diterapkan berdasarkan pendekatan PBL (Problem Based Learning). Pada tahap ini akan disusun skenario pembelajaran/skenario pelaksanaan perkuliahan (dengan karakteristik utama berupa pengajuan pertanyaan atau masalah, berfokus pada keterkaitan antar disiplin, penyelidikan autentik, menghasilkan karya serta mempresentasikannya, dan kerjasama). Secara garis besar prinsip yang digunakan adalah melibatkan mahasiswa bekerja pada masalah (kasus-kasus akuntansi) dalam kelompok kecil. Masalah disiapkan sebagai konteks pembelajaran baru. Analisis dan penyelesaian terhadap masalah itu menghasilkan perolehan pengetahuan dan keterampilan pemecahan masalah. Permasalahan dihadapkan sebelum semua pengetahuan relevan diperoleh dan tidak hanya setelah membaca teks atau mendengar ceramah tentang materi subjek yang melatarbelakangi masalah tersebut. Hasil dari proses pemecahan masalah itu adalah, mahasiswa membangun pertanyaan-pertanyaan (isu pembelajaran) tentang jenis pengatahuan apa yang diperlukan untuk menyelesaikan masalah. Setelah itu, mahasiswa melakukan pengkajian pada isu-isu pembelajaran yang telah diidentifikasi dengan menggunakan berbagai sumber. Untuk ini mahasiswa disediakan waktu yang cukup untuk belajar mandiri. Proses pembelajaran akan menjadi lengkap bila mahasiswa melaporkan hasil (apa yang dipelajari) pada pertemuan berikutnya.

Setelah Silabus dan SAP selesai disusun kemudian disiapkan kasus-kasus akuntansi yang mencerminkan kegiatan riil di dunia kerja. Kasus akuntansi ini diharapkan akan dapat memancing meningkatnya kemampuan analisis dalam penyelesaian terhadap masalah sehingga akan menghasilkan perolehan pengetahuan dan keterampilan pemecahan masalah. Kasus yang disusun juga dikaitkan dengan disiplin lain seperti perbankan, pajak, asuransi, penggajian dan lainnya. Bersamaan dengan penyusunan kasus akuntansi disusun pula bahan ajar atau modul yang dimanfaat- kan oleh mahasiswa dalam proses belajar mengajar.

Setelah tahap desain selesai dilakukan maka dilanjutkan pada tahap pengembangan. Pada tahap ini dilakukan pengembangan/penyempurnaan perangkat pembelajaran yang telah didesain pada tahap sebelumnya. Penyempurnaan ini dilakukan dengan analisis hasil dengan melibatkan rekan seprofesi serta rekan ahli. Peran rekan seprofesi sesama Dosen Jurusan Akuntansi disini adalah memberikan masukan atas substansi perkuliahan mulai dari bagaimana penyusunan kasus- kasus akuntansi sehingga bisa mendekati kondisi real di lapangan, bagaimana kasus akuntansi yang disusun bisa lebih komprehensif saling terkait dengan bidang lainnya seperti: asuransi, perbankan, bisnis dan perpajakan. Keterlibatan rekan seprofesi juga ikut memberikan masukan dalam bagaimana mengemas sistem akuntansi baik untuk perusahaan jasa, dagang maupun perusahaan manufaktur sehingga dapat mengembangkan pola pikir kritis mahasiswa. Sedangkan rekan ahli yang digunakan perannya dalam penelitian ini adalah rekan-rekan ahli pembelajaran terutama ahli pembelajaran di bidang ekonomi termasuk juga dalam bidang evaluasi pendidikan. Peranan rekan ahli disini adalah ikut dalam menyempurnakan perangkat pembelajaran mulai dari Silabus Mata Kuliah, Satuan Acara Pembelajaran, Strategi Pembelajaran, Analisis Instruksional, Asesmen sampai dengan alat bantu pembelajaran berupa media kasus akuntansi berbasis Problem Based Learning. Berdasarkan analisis hasil tersebut maka diperoleh berbagai masukan yang digunakan sebagai bahan penyempurnaan model pembelajaran dan perangkat pembelajaran sehingga produk tersebut siap untuk diimplementasikan.

Pada pertemuan awal ujicoba dalam perkuliahan di kelas merupakan sesion awal/pengenalan mata kuliah dan pemantapan dasar prasyarat perkuliahan. Pertama dilakukan pengenalan mata kuliah termasuk juga kontrak kuliah berupa penjelasan silabus mata kuliah dan Satuan Acara Pembelajaran. Dalam tahap ini dijelaskan secara detail apa standar kompetensi mata kuliah, tujuan pembelajaran, materi-materi yang akan dibahas, metode pengajaran termasuk rencana pembelajaran setiap pertemuan dan bagaimana metode penilaian yang akan dilakukan. Selain itu juga dilakukan diskusi mengenai bagaimana proses belajar mengajar yang diharapkan mahasiswa disesuaikan dengan perencanaan yang sebelumnya 
telah disusun. Tahap berikutnya adalah pemantapan dasar prasyarat perkuliahan.

Materi pembelajaran yang telah dipersiapkan dikelompokkan menjadi tiga kelompok materi sesuai dengan pengelompokan jenis usaha yaitu: siklus akuntansi untuk perusahaan jasa, dagang dan manufaktur. Dengan masing masing kelompok materi memerlukan sekitar 5 kali pertemuan. Sitematika perkuliahan selalu diawali dengan penguasaan materi secara praktek individu untuk satu kasus, setelah praktek individu tuntas baru dilanjutkan dengan kegiatan kelompok. Dalam kegiatan kelompok ini otomatisasi siklus akuntansi disekenariokan seperti di dunia kerja dengan pembagian masing-masing departemen akuntansi yang menjalankan fungsinya sesuai dengan sistem akuntansi. Pembagian departemen tersebut meliputi departemen umum yang mengurus transaksi-transaksi umum perusahaan seperti : penyetoran modal, asuransi dan kredit usaha. Departemen berikutnya adalah departemen penjualan yang mengurus berbagai transaksi penjualan barang dagangan baik tunai maupun kredit. Depatemen pembelian mengurus berbagai transaksi pembelian barang dagangan baik secara tunia maupun kredit. Departemen persediaan me- ngurus berbagai aktivitas menyangkut mutasi persediaan dan departemen penggajian yang mengurus transaksi penggajian termasuk perpajakannya.

Setelah kegiatan kelompok tuntas dilakukan maka kegiatan berikutnya adalah kegiatan mandiri. Maksud dari kegiatan madiri ini adalah mahasiswa diharapkan dapat membuat sistem siklus akuntansi sendiri dengan program komputer akuntansi. Dalam kegiatan ini mahasiswa melakukan survei langsung ke lapangan di dunia usaha sesuai dengan minat mereka. Dari hasil survei ini mereka akan merancang sendiri program siklus akuntansinya kemudian mereka implementasikan dalam pertemuan di kelas diiringi dengan presentasi dan diskusi.

Dalam pelaksanaan perkuliahan aktivitas mahasiswa diamati terutama dalam hal penguasaan akan skill komputer dan keaktifan dalam sesion diskusi serta kemampuan mempresentasikan hasil belajar termasuk dalam hal kehadiran mahasiswa. Penilaian untuk aktivitas mahasiswa ini dikelompokkan ke dalam tiga sesi yaitu untuk sesi siklus akuntansi untuk perusahaan jasa, dagang dan manufaktur. Hasil belajar tersebut dapat dilihat dalam Tabel 1.

Tabel 1. Hasil Belajar dari Aktivitas Mahasiswa di Kelas

\begin{tabular}{lllccccc}
\hline \multirow{2}{*}{ No. } & \multicolumn{1}{c}{ Keterangan } & \multicolumn{3}{c}{ Persentase Jumlah Mahasiswa dengan Nilai } \\
\cline { 3 - 7 } & & $\mathbf{0 - 3 9}$ & $\mathbf{4 0 - 5 4}$ & $\mathbf{5 5 - 6 9}$ & $\mathbf{7 0 - 8 4}$ & $\mathbf{8 5 - 1 0 0}$ & Total \\
\hline 1 & Siklus akuntansi untuk perusahaan jasa & $0 \%$ & $0 \%$ & $8 \%$ & $36 \%$ & $56 \%$ & $100 \%$ \\
\hline 2 & $\begin{array}{l}\text { Siklus akuntansi untuk perusahaan } \\
\text { dagang }\end{array}$ & $0 \%$ & $0 \%$ & $4 \%$ & $44 \%$ & $52 \%$ & $100 \%$ \\
\hline 3 & $\begin{array}{l}\text { Siklus akuntansi untuk perusahaan } \\
\text { manufaktur }\end{array}$ & $0 \%$ & $0 \%$ & $6 \%$ & $34 \%$ & $60 \%$ & $100 \%$ \\
\hline
\end{tabular}

Sedangkan penilaian terhadap mahasiswa juga dilakukan terhadap tugas-tugas yang mereka kerjakan (dalam bentuk portofolio). Tagihan dalam bentuk portofolio ini juga dikatagorikan dalam tiga kelompok yaitu untuk siklus akuntansi untuk perusahaan jasa, dagang dan manufaktur.
Di dalam masing-masing kelompok tersebut tagihan juga dikategorikan dalam tugas individu, kelompok dan perancangan sistem siklus akuntansi secara mandiri. Hasil belajar tersebut dapat dilihat dalam Tabel 2.

Tabel 2. Hasil Belajar dari Tugas-tugas yang Dikumpulkan Mahasiswa

\begin{tabular}{llcccccc}
\hline \multirow{2}{*}{ No. } & \multicolumn{1}{c}{ Keterangan } & \multicolumn{5}{c}{ Persentase Jumlah Mahasiswa dengan Nilai } \\
\cline { 3 - 7 } & Siklus akuntansi untuk perusahaan jasa & $0 \%$ & $0 \%$ & $6 \%$ & $28 \%$ & $66 \%$ & $100 \%$ \\
\hline 1 & $\begin{array}{l}\mathbf{0 - 3 9} \\
\begin{array}{l}\text { Siklus akuntansi untuk perusahaan } \\
\text { dagang }\end{array}\end{array}$ & $0 \%$ & $0 \%$ & $4 \%$ & $36 \%$ & $60 \%$ & $100 \%$ \\
\hline $\begin{array}{l}\text { Siklus akuntansi untuk perusahaan } \\
\text { manufaktur }\end{array}$ & $0 \%$ & $0 \%$ & $4 \%$ & $24 \%$ & $72 \%$ & $100 \%$ \\
\hline
\end{tabular}

Penilaian terhadap hasil belajar mahasiswa juga dilakukan dalam bentuk tes praktek. Tes praktek ini dilakukan sebanyak dua kali yaitu di tengah semester dalam bentuk Ujian Tengah Semester dan di akhir semester dalam bentuk Ujian Akhir Semester. Materi dalam tes praktek ini 
adalah dalam bentuk kasus akuntansi yang harus diselesaikan oleh mahasiswa dengan menyeting sendiri siklus akuntansi dan dikerjakan selama dua jam. Hasil dari tes praktek ini dapat dilihat dalam Tabel 3.

Tabel 3. Hasil Tes Praktek Mahasiswa

\begin{tabular}{llcccccc}
\hline \multirow{2}{*}{ No. } & \multirow{2}{*}{ Keterangan } & \multicolumn{5}{c}{ Persentase Jumlah Mahasiswa dengan Nilai } \\
\cline { 3 - 8 } & & $\mathbf{0 - 3 9}$ & $\mathbf{4 0 - 5 4}$ & $\mathbf{5 5 - 6 9}$ & $\mathbf{7 0 - 8 4}$ & $\mathbf{8 5 - 1 0 0}$ & Total \\
\hline 1 & Ujian tengah semester & $0 \%$ & $0 \%$ & $0 \%$ & $34 \%$ & $64 \%$ & $100 \%$ \\
\hline 2 & Ujian akhir semester & $0 \%$ & $0 \%$ & $0 \%$ & $30 \%$ & $70 \%$ & $100 \%$ \\
\hline
\end{tabular}

Hasil belajar akhir mahasiswa merupakan hasil penggabungan ketiga nilai yaitu: nilai dari aktivitas belajar, nilai tugas dan nilai tes praktek dengan bobot masing-masing yaitu: $35 \%, 35 \%$ dan $30 \%$. Hasil belajar akhir mahasiswa dapat dilihat pada Tabel 4 .

Tabel 4. Hasil Belajar Akhir/ Final Mahasiswa

\begin{tabular}{|c|c|c|c|c|c|c|c|}
\hline \multirow{2}{*}{ No. } & \multirow{2}{*}{ Keterangan } & \multicolumn{6}{|c|}{ Persentase Jumlah Mahasiswa dengan Nilai } \\
\hline & & 0-39 & $40-54$ & $55-69$ & $70-84$ & $85-100$ & Total \\
\hline 1 & Hasil belajar final & $0 \%$ & $0 \%$ & $2 \%$ & $40 \%$ & $68 \%$ & $100 \%$ \\
\hline
\end{tabular}

Hasil uji coba menujukkan tingkat penguasaan mahasiswa sangat bagus yang ditunjukkan dari hasil belajar mereka. Hasil penelitian menunjukkan bahwa: (1) produk penelitian dapat dimanfaatkan sebagai wadah pembelajaran bagi mahasiswa untuk mengulas secara mendalam pemahaman teori akuntansi, sistem akuntansi serta kemampuan didalam memanfaatkan kemajuan teknologi untuk menyelesaikan kasus-kasus akuntansi, (2) produk penelitian dapat dimanfaatkan sebagai alat bantu dalam interaksi pembelajaran, (3) produk penelitian dapat digunakan sebagai sumber belajar.

\section{SIMPULAN}

Berdasarkan hasil penelitian menunjukkan implementasi penelitian pada tahun pertama (2014) baru pada tahapan Determinasi Masalah (Problem Determination) dan Desain (Design). Produk penelitian menghasilkan draf model komputerisasi siklus akuntansi berbasis Problem

\section{DAFTAR RUJUKAN}

Albertus Ong. 2001. Menguasai MYOB Accounting 10 dan Time Billing. Jakarta: Elex Media Komputindo.

AL. Haryono Jusup. 2012. Dasar-dasar Akuntansi. Jilid 1. Yogyakarta: STIE YKPN.

Arnyana. 2005. Pengaruh Penerapan Model PBL Dipandu Strategi Kooperatif Terhadap Kecakapan Berfikir Kritis Siswa SMA pada Mata Pelajaran Biologi. Jurnal Pendidikan dan Pengajaran, 38, 646-667.
Based Learning yang siap untuk diujicobakan pada penelitian pada tahun berikutnya. Sedangkan hasil ujicoba dalam penelitian pada tahun kedua (2015) menunjukkan bahwa hasil pengembangan dapat dimanfaatkan sebagai wadah pembelajaran bagi mahasiswa untuk mengulas secara mendalam pemahaman teori akuntansi, sistem akuntansi serta kemampuan didalam memanfaatkan kemajuan teknologi untuk menyelesaikan kasus-kasus akuntansi. Hasil penelitian menunjukkan bahwa: (1) produk penelitian dapat dimanfaatkan sebagai wadah pembelajaran bagi mahasiswa untuk mengulas secara mendalam pemahaman teori akuntansi, sistem akuntansi serta kemampuan dalam memanfaatkan kemajuan teknologi untuk menyelesaikan kasus-kasus akuntansi, (2) produk penelitian dapat dimanfaatkan sebagai alat bantu dalam interaksi pembelajaran, (3) produk penelitian dapat digunakan sebagai sumber belajar.

Erni Sulindawati. 2013. Pengembangan Perangkat Pembelajaran Akuntansi Keuangan I Berbasis Masalah untuk Meningkatkan Kualitas Pembelajaran Jurnal Media Komunikasi FIS Volume. 12, No.2, Agustus 2013, 98-205.

Gagne, R M.. Briggs, Leslie J., Wager \& Walter W. .1988. Principles of Instructional Design. 3rd. Edition. New York: Holt Rinehart and Winston, Inc.. 
Ibrahim,M. \& Nur, Moh. (2004). Pengajaran Berbasis Masalah. Surabaya: University Press.

Universitas Pendidikan Ganesha Singaraja. 2012. Profil Jurusan Akuntansi

Universitas Pendidikan Ganesha Singaraja. 2012. Buku Pedoman Studi Tahun 2011. Edisi Revisi

Imam Ghozali \& John Castellan. 2002. Statistik Non Parametrik. Semarang: Universitas Diponegoro.

Johar Arifin . 2010. Trik Akuntansi dengan Dac Easy Accounting \& MYOB Accounting. Jakarta: Elex Media Komputindo.

Johar Arifin. 2004. Aplikasi Excel dalam Studi Akuntansi dan Manajemen Keuangan. Jakarta: Elex Media Komputindo.

Johnson, E.B. 2002. Contextual Teching and Learning. California: Corwin Press.
Keiso, Donald E \& Weygad, Jerry J. 2011. Intermediate Accounting. Jakarta: Penerbit Erlangga.

Lucy Sri Musmini \& Adi Yuniarta. 2011. Pengembangan Perangkat Visualisasi Komputer Sistem Akuntansi Berbasis ICT dengan Model PembelajaranBerpendekatan Contextual Teaching And Learning. Laporan Penelitian tidak diterbitkan. Singaraja: Undiksha.

Mulyadi. 2011. Sistem Informasi Akuntansi. Yogyakarta: BPFE

Soemarso S.R. 2012. Akuntansi Suatu Pengantar . Jakarta: Rineka Cipta.

Suharsono, Naswan . 1991. Model Pembelajaran Pemecahan Masalah: Penerapan di Bidang Bisnis. Disertasi tidak diterbitkan. Malang: Program Pascasarjana IKIP Malang.

Wina Sanjaya. 2006. Strategi Pembelajaran Berorientasi Standar Proses Pendidikan. Jakarta: Kencana Prenada Media Group. 